\title{
Retinopathy in severe aplastic anaemia
}

\author{
Harathy Selvan (1), Shorya Vardhan Azad, Priyanka Ramesh, \\ Kusumitha Bhakthaganesh
}

Ophthalmology, Dr Rajendra Prasad Centre for Ophthalmic Sciences, AllMS, New Delhi, India

\section{Correspondence to}

Dr Harathy Selvan; sharathy2012@gmail.com

Accepted 25 September 2019

\section{DESCRIPTION}

A 19-year-old girl presented to the emergency services with complaints of haematuria, gum bleeding and sudden visual loss. General examination revealed significant pallor and multiple petechiae all over the body. Her heart rate was 98 beats/min, blood pressure $102 / 58 \mathrm{~mm} \mathrm{Hg}$, respiratory rate 18 breaths/min and SpO2 99\%. The best corrected visual acuity was counting fingers at $2 \mathrm{~m}$ in the right eye and at $1 \mathrm{~m}$ in left eye. The anterior segment of both eyes (BE) was within normal limits. On dilated fundus examination, $\mathrm{BE}$ showed extensive preretinal, intraretinal and subretinal haemorrhages, numerous Roth spots, hard exudates and masses of organising haemorrhages (figure 1). Macular optical coherence tomography showed BE subinternal limiting membrane bleeds, intraretinal oedema and neurosensory detachments (figure 2).

On investigating, her haemoglobin $(\mathrm{Hb})$ was $28 \mathrm{~g} / \mathrm{L}$, haematocrit $8.2 \%$, platelet count $1000 / \mathrm{mm}^{3}$ and leucocyte count $2.2 \times 10^{9} / \mathrm{L}$. She was referred to a haematologist for detailed evaluation and advised to refrain from eye rubbing, Valsalva manoeuvres and vigorous activities. Bone marrow examination revealed pancytopaenia with a hypocellular marrow. A diagnosis of aplastic anaemia with anaemic retinopathy was made and treated with packed red blood cells and platelet rich plasma.

Anaemic retinopathy is fairly common, especially when the $\mathrm{Hb}$ levels are $<80 \mathrm{~g} / \mathrm{L} .^{1}$ In the presence of anaemia and/or thrombocytopaenia, the prevalence of retinopathy was found to be $28.3 \%$, which further rose to $38 \%$ when both the conditions coexisted. ${ }^{2}$ Nevertheless, in view of its subtle nature not affecting the visual acuity, it frequently remains undetected or under diagnosed. Ironically, anaemia and thrombocytopaenia in the setting of aplastic anaemia can be potentially blinding. Retinopathy was observed in $69 \%$ of aplastic anaemia patients who showed an
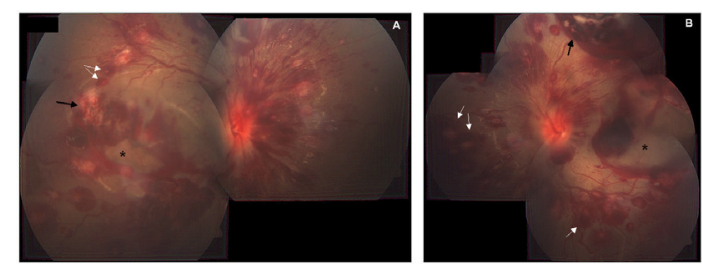

Figure 1 Montage fundus images. (A) Right eye and (B) left eye, showing extensive preretinal, intraretinal and subretinal haemorrhages, numerous Roth spots (white arrows), neurosensory detachments (black *) and masses of organising haemorrhages (black arrows).

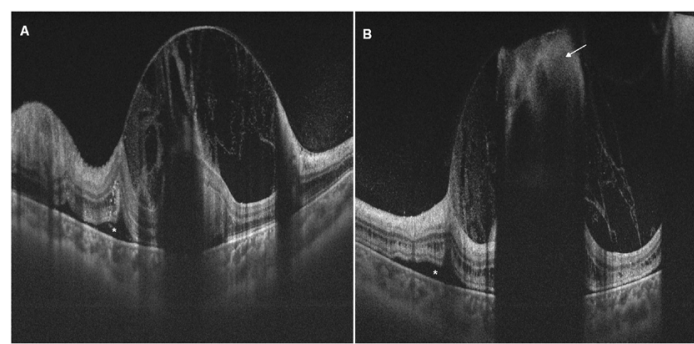

Figure 2 Macular optical coherence tomography images. (A) Right eye and (B) left eye, showing subinternal limiting membrane bleeds, hyper-reflective inner retinal layers, intraretinal cystic spaces and neurosensory detachments (white *). Dense haemorrhage (white arrow) blocking the visibility of underlying structures in the left eye.

\section{Learning points}

- Anaemic retinopathy is fairly common, especially when the haemoglobin levels are $<8 \mathrm{~g} \%$.

- Anaemia and thrombocytopaenia in the setting of aplastic anaemia can be potentially blinding.

- Blood turbulence, endothelial injury and bleeding diathesis have been shown to contribute to the occurrence of haemorrhages in aplastic anaemia.

$\mathrm{Hb}<80 \mathrm{~g} / \mathrm{L}$ and platelet counts of $<50 \times 10^{9} / \mathrm{L}^{3}$ They may present with retinal and vitreous haemorrhages, cotton wool spots, central retinal venous occlusion-like, optic disc oedema, macular oedema, peripheral retinal vasculopathy, orbital and lid hematomas. ${ }^{4-6}$ Blood turbulence, endothelial injury and bleeding diathesis have been shown to contribute to the occurrence of these haemorrhages. ${ }^{4}$ Retinopathy presenting as severe as in this case with sudden loss of vision is a rarity.

Management of anaemic retinopathy involves reassurance and careful observation, as the condition is bound to improve on treatment of the underlying aetiology and correction of anaemia. ${ }^{7}$ Small haemorrhages usually respond to blood transfusions while large haemorrhages threatening vision may require a hyaloidotomy or pars plana vitrectomy. ${ }^{4}$ Such severe presentations though rare, are important to be known, for prompt management to avoid permanent visual loss.

Contributors HS and SVA evaluated and managed the patient. $P R$ and $K B$ collected the data. All four authors were involved in the preparation and critical review of the manuscript. 
Images in...

Funding The authors have not declared a specific grant for this research from any funding agency in the public, commercial or not-for-profit sectors.

Competing interests None declared.

Patient consent for publication Obtained.

Provenance and peer review Not commissioned; externally peer reviewed.

ORCID iD

Harathy Selvan http://orcid.org/0000-0003-4403-8767

\section{REFERENCES}

1 Merin S, Freund M. Retinopathy in severe anemia. Am J Ophthalmol 1968;66:1102-6.
2 Carraro MC, Rossetti L, Gerli GC. Prevalence of retinopathy in patients with anemia or thrombocytopenia. Eur J Haematol 2001;67:238-44.

3 Alameddine R, Mansour A, Lee JW, et al. Ocular findings in aplastic anemia: multicenter study and literature review. Invest Ophthalmol Vis Sci 2013;54.

4 Mansour AM, Lee JW, Yahng SA, et al. Ocular manifestations of idiopathic aplastic anemia: retrospective study and literature review. Clin Ophthalmol 2014;8:777-87.

5 Mansour AM, Salti HI, Han DP, et al. Ocular findings in aplastic anemia. Ophthalmologica 2000;214:399-402.

6 Lee AR, Bhullar PK, Fekrat S. Aplastic anemia presenting with bilateral, symmetric preretinal macular hemorrhages. Can J Ophthalmol 2016;51:e159-60.

7 Tripathy K, Chawla R. Anaemic retinopathy. BMJ 2016;352.

Copyright 2019 BMJ Publishing Group. All rights reserved. For permission to reuse any of this content visit https://www.bmj.com/company/products-services/rights-and-licensing/permissions/

BMJ Case Report Fellows may re-use this article for personal use and teaching without any further permission.

Become a Fellow of BMJ Case Reports today and you can:

- Submit as many cases as you like

- Enjoy fast sympathetic peer review and rapid publication of accepted articles

- Access all the published articles

Re-use any of the published material for personal use and teaching without further permission

Customer Service

If you have any further queries about your subscription, please contact our customer services team on +44 (0) 2071111105 or via email at support@bmj.com.

Visit casereports.bmj.com for more articles like this and to become a Fellow 